\title{
REPEATED SEQUENCE DNA COMPARISONS BETWEEN TRITICUM AND AEGILOPS SPECIES
}

\author{
RICHARD FLAVELL, MICHAEL O'DELL and DEREK SMITH \\ Department of Cytogenetics, Plant Breeding Institute, Trumpington, Cambridge CB2 2LQ
}

Received 28.xi.78

\section{SUMMARY}

The families of repeated sequences in the genomes of a range of Triticum and Aegilops species have been compared. All the genomes are very similar. However, using a DNA probe from Aegilops speltoides that contains the most highly repeated sequences, diploid Aegilops species could be distinguished from diploid Triticum species. Different Aegilops species' DNAs also hybridise to differing extents with this probe. The results are consistent with the hypothesis that speciation is accompanied by quantitative changes in the repeated sequence complements of genomes.

Most if not all of the families of repeated sequences in hexaploid wheat can be detected in Aegilops speltoides (related to the B genome) and in Aegilops squarrosa (related to the D genome). However, some families of repeated sequences of hexaploid wheat were not found in Triticum monococcum (related to the A genome). Some of the most highly repeated sequences of hexaploid wheat are preferentially concentrated in the B genome. These sequences are useful as probes for distinguishing the three diploid genomes of hexaploid wheat.

\section{INTRODUGTION}

THE repeated sequence complements of complex genomes can change considerably during species divergence. Easily detectable differences are often found between the repeated sequences in related species (Chooi, 1971; Goldberg et al., 1972; Rice, 1972; Straus, 1972; Rice and Esposito, 1973; Stein and Thompson, 1975; Mizuno et al., 1976; Barnes et al., 1978). In general, the extent of repeated sequence DNA homology between species is related to their phylogenetic similarity concluded from classical taxonomic assessments, i.e. more closely related species have more families of repeated sequences in common. Previous studies in this laboratory (Smith and Flavell, 1974; Flavell et al., 1977; Rimpau et al., 1978) as well as from other laboratories (Bendich and McCarthy, 1970) have shown this to be true for oats, barley, wheat and rye, members of the Gramineae, which have diverged from a common ancestor (Bell, 1965; Flavell et al., 1977). However, each of these species also possesses species-specific families of repeated sequences and we have recently illustrated how these can be used to detect rye and barley chromosome fragments in a wheat nucleus (Flavell et al., 1978).

Hexaploid wheat is an allohexaploid $(2 n=6 x=42)$ with a Triticum species (Triticum monococcum) and two Aegilops species (Ae. squarrosa and Ae. speltoides or a close relative) as the three diploid $(2 n=2 x=14)$ parents. Some repeated sequence DNA comparisons between these diploid genomes were reported by Bendich and McCarthy in 1970. We wished to extend these comparisons paying particular attention to very high copy number repeats which frequently include species-specific families of repeated sequences. Our results, reported in this paper, show that Triticum and 
Aegilops species do have small repeated sequence differences and these are useful for distinguishing the diploid parents of hexaploid wheat.

\section{Materials and methods}

\section{(i) Plant genotypes}

The wheat (Triticum aestivum) variety Chinese Spring and rye (Secale cereale) variety Petkus were used as sources of wheat and rye DNA. Seed of the other species used for DNA isolation were from stocks kept at the Plant Breeding Institute.

\section{(ii) Isolation of unlabelled and in vivo labelled $D \mathcal{N} A s$}

Unlabelled DNAs were isolated from green leaf tissue of plants grown under continuous illumination. The details of the DNA purification have been described previously. (Smith and Flavell, 1974). In vivo tritium labelled wheat DNA was purified from about 3-day-old dark grown seedlings, germinated in the presence of $\left(\mathrm{Me}^{3} \mathrm{H}\right)$ thymidine also as described previously (Smith and Flavell, 1974). It had a specific activity of about 40,000 $\mathrm{cpm} / \mu \mathrm{g}$. All DNAs were sheared by sonication, in an ice bath, to give weight average, denatured fragment lengths between 300 and 400 nucleotides. Average fragment sizes were determined by boundary velocity sedimentation in $0.9 \mathrm{M} \mathrm{NaCl} 0.1 \mathrm{M} \mathrm{NaOH}$ as described by Studier (1965) using an MSE "Centriscan" analytical ultracentrifuge.

\section{(iii) Renaturation of denatured $D \mathcal{N} A$ in solution and $S_{1}$ nuclease treatment}

In the experiments where the renatured duplexes were to be treated with $\mathrm{S}_{1}$ nuclease, renaturation of the sheared, denatured labelled wheat plus unlabelled DNAs was carried out in $0.3 \mathrm{M} \mathrm{NaCl} 0.01 \mathrm{~m}$ Pipes buffer pH 6.8 at $65^{\circ} \mathrm{C}$. The DNAs were denatured by heating to $100^{\circ} \mathrm{C}$ for $5 \mathrm{~min}$. After incubation to the desired $\mathrm{C}_{0} \mathrm{t}\left(\mathrm{C}_{0} \mathrm{t}=\right.$ moles nucleotide per litre $\times$ incubation time in sec.) an equal volume of $0.05 \mathrm{~m}$ sodium acetate buffer $p \mathrm{H} 4.3$ containing $0.2 \mathrm{~mm} \mathrm{Zn}^{++}$and $5.5 \mathrm{~mm}$ mercaptoethanol was added to bring the $p \mathrm{H}$ to $4 \cdot 3$. Enough $\mathrm{S}_{1}$ nuclease, purified by the method of Sutton (1971), was added to be able to digest all the DNA, if it were single stranded, during a $60 \mathrm{~min}$. incubation at $37^{\circ} \mathrm{C}$. After incubation of the DNA with $\mathrm{S}_{1}$ nuclease for $60 \mathrm{~min}$. at $37^{\circ} \mathrm{C}, 100 \mu \mathrm{g}$ of bovine serum albumin and TCA ( 5 per cent final concentration), were added and the precipitate collected on GF/B glass fibre filters after standing at $3^{\circ} \mathrm{C}$ for at least 1 hour (Flavell and Smith, 1976). The filters were dried and their radioactivity determined in a scintillation counter.

In the experiments where the very rapidly renaturing " nick translated" Ae. speltoides and $T$. monococcum DNAs were incubated with unlabelled DNAs in solution, renaturation was carried out at $60^{\circ} \mathrm{C}$ or $68^{\circ} \mathrm{C}$ in $0.12 \mathrm{M}$ phosphate buffer $p \mathrm{H} 6 \cdot 8$. After renaturation, the renatured fragments were separated from the denatured fragments by hydroxyapatite chromatography at $60^{\circ} \mathrm{C}$ or $68^{\circ} \mathrm{C}$ exactly as described previously (Flavell et al., 1978). The DNAs in both hydroxyapatite fractions were precipitated with TCA and their radioactivity determined as described above. 
(iv) Isolation and radioactive labelling of very rapidly renaturing DNA from Triticum aestivum, Aegilops speltoides and Triticum monococcum

Aliquots of Triticum aestivum, Aegilops speltoides or Triticum monococcum DNA in $0.12 \mathrm{~m}$ phosphate buffer were sheared to give average fragment lengths of about 800 nucleotides, denatured by boiling, incubated at $60^{\circ} \mathrm{C}$ to a $\mathrm{C}_{0} \mathrm{t}$ of approximately $10^{-2}$ and applied to hydroxyapatite columns. The non-renatured DNA was eluted with $0.12 \mathrm{~m}$ phosphate buffer at $60^{\circ} \mathrm{G}$. The DNA fragments containing renatured regions were eluted with $0.5 \mathrm{M}$ phosphate buffer $p \mathrm{H} 6.8$ at $60^{\circ} \mathrm{C}$. This DNA was radioactively labelled in vitro (" nick translated") as described by Flavell et al. (1978).

(v) Hybridisation of " nick translated" Triticum aestivum and Aegilops speltoides $D \mathcal{N} A$ s to filter-bound unlabelled $D \mathcal{N} A s$

Unlabelled DNAs in $0.1 \times \mathrm{SSC}$ (SSC $=0.15 \mathrm{~m}$ sodium chloride $0.015 \mathrm{M}$ sodium citrate) were denatured with an equal volume of $1 \mathrm{~m} \mathrm{NaOH}$. After approximately $15 \mathrm{~min} ., 4$ volumes of a $2: 1: 1$ mixture of $3 \mathrm{~m} \mathrm{NaCl}, 1 \mathrm{M}$ tris-HCl $(p \mathrm{H} \mathrm{8.0)}$ and $1 \mathrm{~N} \mathrm{HCl}$ were added. The solutions were passed under gravity through $10 \mathrm{~mm}$ diameter Millipore HAWP filters and the filters washed with $5 \mathrm{ml}$ of $6 \times \mathrm{SSC}$. After drying in air the filters were stored at $-20^{\circ} \mathrm{C}$ until use. Immediately before hybridisation, the filters were heated at $80^{\circ} \mathrm{C}$ in vacuo for 2 hours. Approximately $25 \mu \mathrm{g}$ of DNA was bound per filter.

For the typical hybridisation reaction, filter-bound DNAs of each of the genotypes to be compared were incubated together at $40^{\circ} \mathrm{C}$ for 16 hours in $2 \times \operatorname{SSC} 50$ per cent formamide containing approximately 1 to $2 \times 10^{-3} \mu \mathrm{g}$ labelled DNA per filter. Five replicate filters of each DNA were usually included and approximately four filters were incubated per $\mathrm{ml}$ of solution. The amount of DNA bound to each filter was determined after hybridisation and scintillation counting, by hydrolysing the DNA in $\mathrm{HCl}$ (Brown and Weber, 1968). Filters lacking DNA were included as controls in all experiments. All results (see tables 2 and 3) are corrected for the results obtained from these control blank filters.

\section{Results}

(i) Comparison of the repeated sequences in Triticum monococcum (2x), Aegilops speltoides $(2 x)$, Aegilops squarrosa (2x), Triticum aestivum $(6 x)$ and Secale cereale $(2 x)$

Studies were first carried out to investigate if all the families of repeated sequences in hexaploid wheat, Triticum aestivum, are present in each of the three diploids related to the ancestral diploid progenitors of hexaploid wheat. Secale cereale, rye, was also included in the experiments as a control, as previous studies have shown that wheat possesses families of repeated sequences not found repeated in rye (Flavell et al., 1977). An aliquot of sheared ${ }^{3} \mathrm{H}$ labelled wheat DNA was added to a 10,000 -fold excess of sheared, unlabelled DNA fragments from each of the species, in $0.3 \mathrm{M} \mathrm{NaCl}$ 0.01 м Pipes buffer $p \mathrm{H} 6.8$. The DNAs were denatured and allowed to renature at $65^{\circ} \mathrm{C}$ for different $\mathrm{C}_{0} \mathrm{t}$ values between $10^{-2}$ and 10 . 
In these sorts of experiments, DNA renaturation is driven by the unlabelled DNA which is in sufficient excess over the labelled wheat DNA to virtually eliminate the renaturation of labelled DNA fragments to one another. The extent to which labelled wheat DNA fragments become incorporated into duplexes is therefore a measure of DNA sequence homology between the labelled and unlabelled DNAs. Previous studies (Smith and Flavell, 1975; Flavell and Smith, 1976) have shown that most cereal DNA fragments possessing repeated sequences have renatured by $\mathrm{C}_{0} \mathrm{t} 10$, so most families of repeated sequences were assayed by carrying out incubations to $\mathrm{C}_{0} \mathrm{t} 10$.

After incubation, non-renatured single stranded DNA was digested by incubating with $\mathrm{S}_{1}$ nuclease at $37^{\circ} \mathrm{C}$ for $60 \mathrm{~min}$. (see Materials and Methods). The $S_{1}$ nuclease resistant renatured DNA was then precipitated with TCA and collected on GF/B filters (Flavell and Smith, 1976). After the filters were dried, the ${ }^{3} \mathrm{H}$ wheat DNA surviving the $\mathrm{S}_{1}$ nuclease digestion was estimated. The results are shown as $\mathrm{C}_{0} t$ curves in fig. $l$ for the experiments where five different unlabelled DNAs were used to drive the renaturation of the labelled wheat DNA. The proportion of ${ }^{3} \mathrm{H}$ labelled wheat DNA able to hybridise with rye DNA was clearly less than that able to hybridise to all the other unlabelled DNAs. No clearly significant differences were found between the curves for different unlabelled Triticum and Aegilops DNAs, although there was a hint that hybridisation to $T$. monococcum DNA might be less at high $\mathrm{C}_{0} \mathrm{t}$ values. Thus most if not all of the families of repeated sequences in hexaploid wheat are also in each of the diploid Triticum and Aegilops DNAs.

To examine this more thoroughly, two different preparations of DNA from

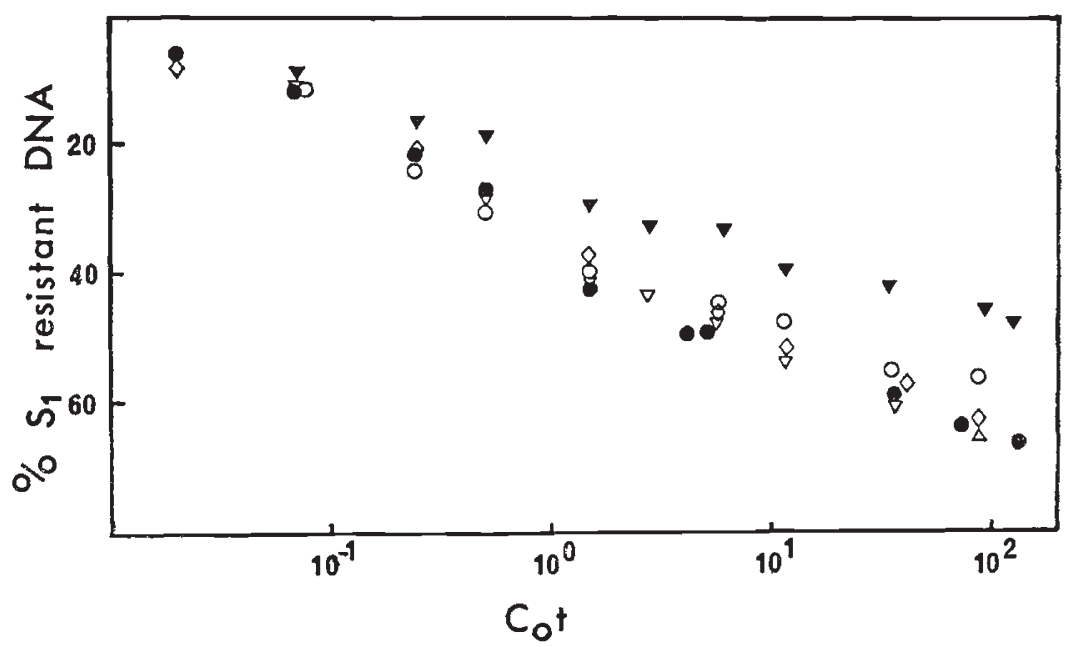

Frg. I.--Hybridisation of ${ }^{3} \mathrm{H}$ labelled hexaploid wheat DNA to Ae. speltoides, Ae. squarrosa, T. monococcum, T. aestivum and Secale cereale DNAs. ${ }^{3} \mathrm{H}$ labelled wheat DNA was incubated with large excesses of sheared denatured unlabelled DNAs in $0.3 \mathrm{M} \mathrm{NaCI} 0.01 \mathrm{M}$ Pipes buffer $p \mathrm{H} 6.8$ at $65^{\circ} \mathrm{C}$ to the $\mathrm{C}_{0}$ t values shown. The proportion of ${ }^{3} \mathrm{H}$ labelled DNA incorporated into duplex DNA and therefore $S_{1}$ nuclease resistant was determined as described in Materials and Methods: $\nabla$ Secale cereale, $\bigcirc$ T. monococcum, $\nabla$ Ae. speltoides, $\diamond A e$. squarrosa, $\bigcirc$. aestivum. 
Triticum monococcum, Aegilops speltoides, Aegilops squarrosa and Triticum aestivum were renatured in quadruplicate to $\mathrm{C}_{0} \mathrm{t} 100$ with ${ }^{3} \mathrm{H}$ labelled Triticum aestivum DNA. The proportion of ${ }^{3} \mathrm{H}$ labelled wheat DNA hydridised to each unlabelled DNA was determined as described above. The mean values are shown in table 1. Significantly less labelled wheat DNA hybridised to unlabelled Triticum monococcum and Secale cereale than to unlabelled wheat, Aegilops speltoides or Aegilops squarrosa DNA. This implies that some families of repeated sequences occupying approximately 11 per cent and 18 per cent of the wheat genome are not found in the repeated sequence fractions of $T$. monococcum and $S$. cereale respectively.

\section{TABLE 1}

Hybridisation of ${ }^{3} \mathrm{H}$ labelled wheat DNA to $C_{0} t 100$ with unlabelled $D \mathcal{N} A$ s from $\mathrm{T}$. monococcum, Ae. speltoides, Ae. squarrosa and Secale cereale

Unlabelled DNA

T. aestivum $(6 x)$ (i)

(ii)

T. monococcum $(2 x)$

\section{(i)}

(ii)

Ae. speltoides $(2 x)$

(i)

(ii)

Ae. squarrosa $(2 x)$
$\%{ }^{3} \mathrm{H}$ wheat DNA $\mathrm{S}_{1}$ nuclease resistant (mean of four replicates)

$60 \cdot 6$

$66 \cdot 5$

$52 \cdot 9 *$

$51 \cdot 5^{*}$

$59 \cdot 7$

$65 \cdot 0$

$61 \cdot 3$

$58 \cdot 5$

45.3* bility.

* = significantly lower than hybridisation to $T$. aestivum at the 5 per cent level proba-

Denatured ${ }^{3} \mathrm{H}$ labelled wheat DNA was incubated with a 10,000 -fold excess of denatured unlabelled DNA from the species shown to $\mathrm{C}_{0} \mathrm{t} 100$ at $65^{\circ} \mathrm{C}$ in $0.3 \mathrm{M} \mathrm{NaCl} 0.01 \mathrm{~m}$ Pipes $p \mathrm{H}$ 6.8. After $\mathrm{S}_{1}$ nuclease treatment, the $\mathrm{S}_{1}$ nuclease resistant labelled DNA was determined by precipitating with TCA, collecting on a glass fibre filter and counting in a scintillation counter.

(ii) Comparison of the most highly repeated sequences in Triticum aestivum with those of related species

The DNA of Triticum aestivum which renatured by approximately $\mathrm{C}_{0} \mathrm{t}$ $10^{-2}$ was isolated and tritium labelled in vitro by " nick translation" as in Flavell et al. (1978). This DNA includes inverted repeats which renature rapidly due to intrastrand renaturation (Flavell and Smith, 1976), the neighbouring sequences to these inverted repeats which would be on the same fragments, the very highly repeated sequences in excess of approximately $0.25 \times 10^{6}$ copies per constituent haploid genome and their neighbouring sequences.

To study the relative concentrations of the very highly repeated sequences in the species closely related to the constituent genomes of Triticum aestivum, four or five replicate filters loaded with DNA from each species were incubated together in the same solution with a low concentration of labelled 
Triticum aestivum $\mathrm{C}_{0} \mathrm{t} 10^{-2}$ DNA (see Materials and Methods and legend to table 2). In these experiments filter bound unlabelled DNAs are in considerable excess, so the DNAs from the different species compete for the available labelled DNA in solution. Thus, those filter-bound unlabelled DNAs possessing a higher concentration of sequences homologous to those in the $\mathrm{C}_{0} \mathrm{t} 10^{-2} \mathrm{DNA}$ hybridise with a higher proportion of the labelled $\mathrm{C}_{0} \mathrm{t} 10^{-2}$ Triticum aestivum DNA. The labelled DNA which binds to the filters during hybridisation consists of the very highly repeated sequences of Triticum aestivum since the labelled inverted repeats which renature by intrastrand reassociation do not bind to the millipore filters under the hybridisation conditions. The results of the experiments, i.e. the amounts of labelled DNA hybridised to the filters loaded with DNA of each species

TABLE 2

Hybridisation of very rapidly reannealing $D \mathcal{N} A$ from Triticum aestivum to DNAs from related species

Species

Triticum aestivum
Aegilops speltoides
T. dicoccoides
$T$. timopheevi
Aegilops bicornis
Aegilops squarrosa
Triticum boeoticum
$\quad(T$. Thaoudar)
$\quad(T$. Aegilopoides)

Labelled DNA bound to filter $\mathrm{cpm} / \mu \mathrm{g}$ filter bound DNA ${ }^{a}$

$$
\begin{aligned}
& 73 \cdot 6 \pm 2 \cdot 9 \\
& 78 \cdot 3 \pm 5 \cdot 2 \\
& 94 \cdot 9 \pm 1 \cdot 5 * * * \\
& 91 \cdot 3 \pm 2 \cdot 7 * * \\
& 74 \cdot 4 \pm 0 \cdot 9 \\
& 55 \cdot 9 \pm 3 \cdot 1 * * \\
& 49 \cdot 5 \pm 2 \cdot 2 * * * \\
& 45 \cdot 3 \pm 2 \cdot 2 * * *
\end{aligned}
$$

Filters loaded with 20 to $30 \mu \mathrm{g}$ DNA from the species listed above were incubated together for 16 hours at $40^{\circ} \mathrm{C}$ in $2 \times \mathrm{SSC} 50$ per cent formamide containing 4 to $8 \times 10^{-3}$ $\mu \mathrm{g} \mathrm{ml}$ of nick translated $\mathrm{C}_{0} \mathrm{t} 10^{-2}$ DNA from Triticum aestivum.

a Results are mean values \pm standard error of the mean for five replicate filters.

$* *, * * *=$ significantly different from $T$. aestivum at the 1 per cent and $0 \cdot 1$ per cent levels of probability, respectively.

are shown in table 2. Significantly more $\mathrm{C}_{0} \mathrm{t} 10^{-2}$ DNA hybridised to the tetraploid $T$. dicoccoides (genome description $\mathrm{AB}$ ) and $T$. timopheevi (AS; $\mathrm{S}$ is closely related to $\mathrm{B}$ ) DNAs than to hexaploid Triticum aestivum (ABD) DNA. This indicates that $\mathrm{C}_{0} \mathrm{t} \mathbf{1 0}^{-2} \mathrm{DNA}$ contains sequences which are preferentially located in the $\mathrm{A}$ and/or $\mathrm{B}$ genomes of hexaploid wheat. This is supported by the significantly lower hybridisation to Ae. squarrosa (D) DNA. The amounts of $\mathrm{C}_{0} \mathrm{t} 10^{-2}$ hybridising to the Triticum boeoticum diploids related to the $\mathrm{A}$ genome of hexaploid wheat were only approximately 50 per cent that which hybridised to the tetraploids. This indicates, assuming the similarity of the A genomes of the tetraploids and the $T$. boeoticum genome, that the $\mathrm{C}_{0} \mathrm{t} 10^{-2}$ highly repeated sequences of Triticum aestivum come preferentially from the $\mathrm{B}$ genome. The high hybridisation levels of $\mathrm{C}_{0}$ t $10^{-2}$ DNA to Ae. speltoides and Ae. bicornis (very closely related species) are consistent with this conclusion. To investigate further the most highly repeated sequences concentrated in chromosomes related to the $\mathrm{B}$ genome of hexaploid wheat, a $\mathrm{C}_{0} \mathrm{t} 10^{-2}$ fraction was isolated from Ae. speltoides DNA. 
(iii) Comparison of the very highly repeated sequences of Ae. speltoides with those in other Triticum and Aegilops species

The DNA of Ae. speltoides which renatured by $\mathrm{C}_{0} t 10^{-2}$ was isolated and tritium labelled in vitro by "nick translation" as described in Materials and Methods. This fraction was used in two kinds of hybridisation experiments: (1) Where the unlabelled DNAs were denatured and immobilised on millipore filters and (2) where the unlabelled DNAs were sheared and incubated in $0.12 \mathrm{~m}$ phosphate buffer $p \mathrm{H} 6.8$.

To study the relative concentrations, in a range of Triticum and Aegilops species, of the sequences homologous to the very rapidly reannealing sequences of Aegilops speltoides, four to six replicate filters loaded with each of the DNAs were incubated together with the labelled Ae. speltoides DNA. The amounts of labelled DNA hybridised to DNAs from each of the species is shown in table 3 .

More labelled $A e$. speltoides DNA hybridised to unlabelled Ae. speltoides DNA than to any other DNA. Between 60 and 75 per cent of the labelled Ae. speltoides DNA which hybridised to unlabelled Ae. speltoides DNA hybridised with other diploid Aegilops species. The amount of highly repeated

\section{TABLE 3}

Hybridisation of the very highly repeated sequences of Aegilops speltoides to DNAs from related species.

$\begin{array}{ll}\begin{array}{l}\text { Selection } \\ \text { Aegilops genus }\end{array} & \text { Species } \\ \text { Sitopsis } & \\ & \begin{array}{l}\text { Ae. speltoides } \\ \text { Ae. } \text { longissima } \\ \text { Ae. sharonensis } \\ \text { Ae. bicornis }\end{array} \\ \text { Polyeides } & \text { Ae. umbellulata } \\ & \text { Ae. triuncialis } \\ \text { Cylindropyrum } & \text { Ae. caudata } \\ \text { Amblyopyrum } & \text { Ae. mutica } \\ \text { Vertebrata } & \text { Ae. squarrosa } \\ & \text { Ae. crassa }(4 x) \\ & \text { Ae. crassa }(6 x)\end{array}$

Labelled DNA bound to filters $\mathrm{cpm} / \mu \mathrm{g}$ filter bound DNA

Triticum genus (diploids)

$$
\begin{aligned}
& \text { T. monococcum } \\
& \text { T. boeoticum } \\
& \text { T. aegilopoides } \\
& \text { T. thaoudar } \\
& \text { T. urartu }
\end{aligned}
$$

$\overbrace{\text { Expt } 1}^{\text {Expt } 2}$

$\begin{array}{cc}105 \cdot 5 \pm 2 \cdot 9 & 130 \pm 3 \cdot 9 \\ 66 \cdot 7 \pm 3 \cdot 0 & - \\ 72 \cdot 5 \pm 2 \cdot 9 & - \\ - & 102 \pm 2 \cdot 6 \\ 68 \cdot 8 \pm 2 \cdot 1 & - \\ 69 \cdot 9 \pm 5 \cdot 4 & - \\ 67 \cdot 2 \pm 1 \cdot 2 & - \\ 67 \cdot 2 \pm 2 \cdot 5 & - \\ - & 70 \cdot 2 \pm 6 \cdot 5 \\ 50.9 \pm 1 \cdot 2 & - \\ 45.5 \pm 1 \cdot 8 & -\end{array}$

Triticum genus (polyploids)

$$
\begin{aligned}
& \text { T. dicoccoides } \\
& \text { T. timopheevi } \\
& \text { T. aestivum }
\end{aligned}
$$

Calf

$\begin{array}{cc}\text { - } & 49 \cdot 7 \pm 5 \cdot 2 \\ 35 \cdot 5 \pm 4 \cdot 0 & 63 \cdot 0 \pm 5 \cdot 1 \\ \text { - } & 65 \cdot 0 \pm 6 \cdot 4 \\ 21 \cdot 9 \pm 2 \cdot 5 & \end{array}$

Unlabelled DNAs from each species were denatured, immobilised on filters and incubated with trace amounts of ${ }^{3} \mathrm{H}$ labelled Ae. speltoides $\mathrm{C}_{0} \mathrm{t} 10^{-2}$ DNA in $2 \times$ SSC 50 per cent formamide at $40^{\circ} \mathrm{C}$ for 16 hours.

$42 / 3-\mathrm{c}$ 
sequence DNA of $A e$. speltoides that bound to hexaploid and tetraploid wheat DNAs was considerably more than that which bound to Aegilops squarrosa DNA from which the D genome descended and to Triticum monococcum from which the A genome descended. Thus the B genome of hexaploid wheat must be highly enriched with sequences homologous to the very highly repeated sequences in Ae. speltoides. This conclusion supports the notion that the B genome of hexaploid wheat is closely related to an Ae. speltoideslike genome. It is also consistent with the results in Results (ii) which showed that the most highly repeated sequences of hexaploid wheat are preferentially localised in the B genome.

Ae. speltoides labelled DNA hybridised least to DNAs from those diploids classified in the Triticum genus viz. T. monococcum and $T$. boeoticum. The lower hybridisation levels of $A e$. speltoides very rapidly reannealing DNA to diploid Triticum species could be because repeated sequences homologous to those in the Ae. speltoides probe DNA are absent or because they are present but in lower frequency in T. monococcum. This was investigated by incubating labelled rapidly reannealing Ae. speltoides DNA with a 300,000fold excess of $T$. boeoticum DNA (isolates $T$. thaoudar and $T$. aegilopoides) to $\mathrm{C}_{0} \mathrm{t} 10$, a $\mathrm{C}_{0} \mathrm{t}$ value by which most families of repeated sequences have renatured (Flavell and Smith, 1976). The proportion of labelled DNA which renatured was compared with the proportion which renatured to Ae. speltoides, $T$. timopheevi and $T$. dicoccoides DNAs. These lattér DNAs all contain DNAs from Aegilops species. Calf thymus DNA was also included as a non-homologous DNA control. Twenty-five to thirty per cent of the labelled Aegilops speltoides DNA ended up in the duplex fraction in this control experiment (table 4). Much of this DNA probably renatured by intrastrand reassociation rather than by a second order reaction (Flavell and Smith, 1976; Smith and Flavell, 1975 (see also fig. 2)). The other results detailed in table 4 clearly indicate that approximately 20 to 30 per cent of the sequences in the labelled Ae. speltoides DNA which hybridise to

TABLE 4

Hybridisation of highly repeated Aegilops speltoides DNA to repeated sequences from other species

\begin{tabular}{lcc} 
& \multicolumn{2}{c}{$\%$ labelled DNA in duplex fraction ${ }^{\mathbf{a}}$} \\
Unlabelled DNA & $\overbrace{\text { Expt 1 }}$ \\
Calf thymus & $25 \cdot 6$ & Expt 2 \\
Ae. speltoides & 75 & 68 \\
T. timopheevi & 72 & 68 \\
T. boeoticum (T. Thaoudar) & 64 & 58 \\
T. dicoccoides & - & 55 \\
Ae. squarrosa & - & 64 \\
\end{tabular}

a Each figure is the mean of three replicates.

${ }^{3} \mathrm{H}$ labelled Aegilops speltoides very rapidly reannealing DNA was added to sheared unlabelled DNA in a ratio of approximately $1: 300,000$. After denaturation, renaturation was to $\mathrm{C}_{0} \mathrm{t} 10$ at $68^{\circ} \mathrm{C}$ in $0 \cdot 12 \mathrm{M}$ phosphate buffer. The proportion of ${ }^{3} \mathrm{H}$ labelled DNA in the duplex fraction was determined by hydroxyapatite chromatography. The failure of all the ${ }^{3} \mathrm{H}$ labelled DNA to renature to Ae. spelioides unlabelled DNA implies it either contains single copy or low copy number sequences or some of the fragments are very short and consequently are unable to renature. 


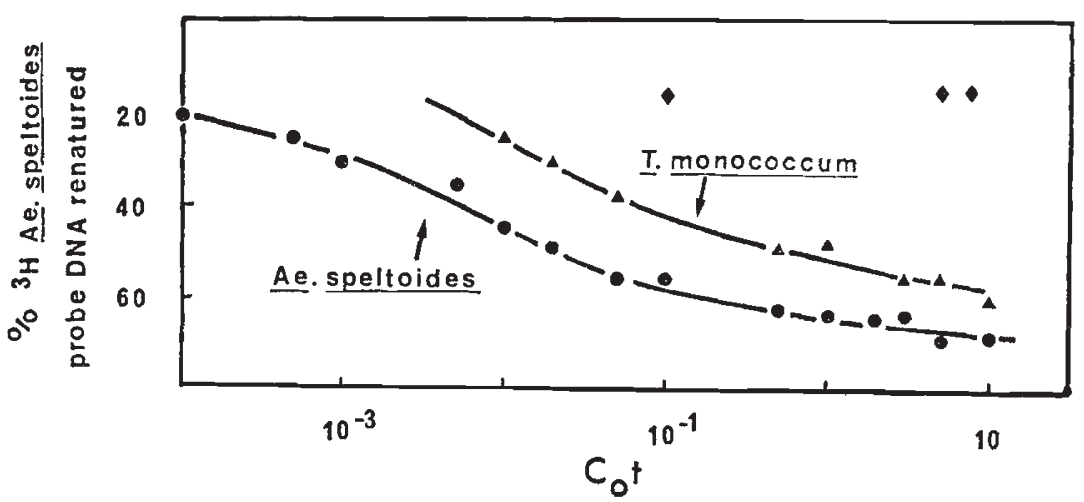

Fig. 2.-Hybridisation kinetics of Ae. speltoides $\mathrm{C}_{0} \mathrm{t} 10^{-2}$ DNA to Ae. speltoides and T. monococcum repeated sequences. "Nick translated" Ae. speltoides $\mathrm{C}_{0} t 10^{-2}$ DNA was incubated with a large excess of denatured, sheared unlabelled Ae. speltoides ( or T. monococcum ( $-\mathbf{\Delta}$ ) DNA in $0.12 \mathrm{~m}$ phosphate buffer at $68^{\circ} \mathrm{C}$. The proportion of labelled DNA in the duplex fraction was determined by hydroxyapatite chromatography. The absence of renaturation of the labelled DNA incubated without unlabelled DNA is shown by

unlabelled Ae. speltoides DNA do not hybridise to T. boeoticum DNA, i.e. there appears to be highly repeated sequences in Ae. speltoides ( 2 to 3 per cent of the genome) which are not repeated, or only a few times so, in $\mathcal{T}$. boeoticum.

The kinetics of renaturation of the labelled, very rapidly reannealing DNA from Ae. speltoides to large excesses of unlabelled Ae. speltoides and T. monococcum DNAs were studied in more detail. The labelled plus unlabelled DNA mixtures were denatured and incubated at $68^{\circ} \mathrm{C}$ in $0.12 \mathrm{~m}$ phosphate buffer to $\mathrm{C}_{0} \mathrm{t}$ values between $10^{-4}$ and 10. The proportions of labelled $A e$. speltoides DNA in the duplex fraction were determined following hydroxyapatite chromatography. The results are shown in fig. 2. The renaturation percentages at $\mathrm{C}_{0} \mathrm{t}$ values 1 to 10 , show that 17 per cent of the labelled DNA that hybridised to $A e$. speltoides DNA (approximately 2 per cent of the $A e$. speltoides genome) was not hybridised with $T$. monococcum DNA. These results endorse those in table 4 . Renaturation of $T$. monococcum sequences homologous to the $A e$. speltoides labelled sequences did not begin until a $\mathrm{C}_{0} \mathrm{t}$ value of approximately $3 \times 10^{-3}$. However, 19 per cent of the Ae. speltoides labelled DNA ( 2 per cent of the Ae. speltoides genome) had renatured by the $\mathrm{C}_{0} \mathrm{t}$ value when $A$ e. speltoides $\mathrm{DNA}$ was driving renaturation of the labelled DNA. This provides further evidence of the difference between the most highly repeated fractions of $T$. monococcum and Ae. speltoides. From the shapes of the renaturation curves in fig. 2 it cannot be unequivocally concluded that the sequences not repeated in $T$. monococcum renature between $\mathrm{C}_{0} \mathrm{t} 10^{-4}$ and $\mathrm{C}_{0} \mathrm{t} 10^{-2}$ in Ae.speltoides DNA. The alternative possibility is that the sequences which renature between $\mathrm{C}_{0} \mathrm{t} 10^{-4}$ and $\mathrm{C}_{0} \mathrm{t} 10^{-2}$ in Ae. speltoides DNA are present in a lower frequency in $T$. monococcum DNA and so renature between $\mathrm{C}_{0} \mathrm{t} 10^{-2}$ and $\mathrm{C}_{0} \mathrm{t} 10$. In this latter situation, the Ae. speltoides highly repeated sequences absent from $T$. monococcum would presumably renature between $\mathrm{C}_{0} \mathrm{t}^{10^{-2}}$ and $\mathrm{C}_{0} \mathrm{t} 10$ in Ae. speltoides DNA.

To test whether $T$. monococcum contains highly repeated sequences not found in Ae. speltoides, a highly repeated sequence fraction (15 per cent of 
the genome) was isolated from T. monococcum, "nick translated" and incubated to a range of $\mathrm{C}_{0} \mathrm{t}$ values with unlabelled $T$. monococcum and $A e$. speltoides DNAs. The results are shown in fig. 3. The renaturation of the highly repeated sequences of $\mathcal{T}$. monococcum to Ae. speltoides and $\mathcal{T}$. monococcum DNAs are very similar, although it appears that a minor fraction (5 per cent) of the labelled DNA (0.5 per cent of $T$. monococcum genome) is not repeated in $A e$. speltoides DNA. The labelled DNA that was in the duplex fraction by $\mathrm{C}_{0} \mathrm{t} 10^{-4}$ consists of reverse repeats that renature by intrastrand reassociation (Flavell and Smith, 1976). Renaturation of labelled $T$. monococcum sequences did not begin until a $\mathrm{C}_{0}$ t value about $10^{--2}$. Thus

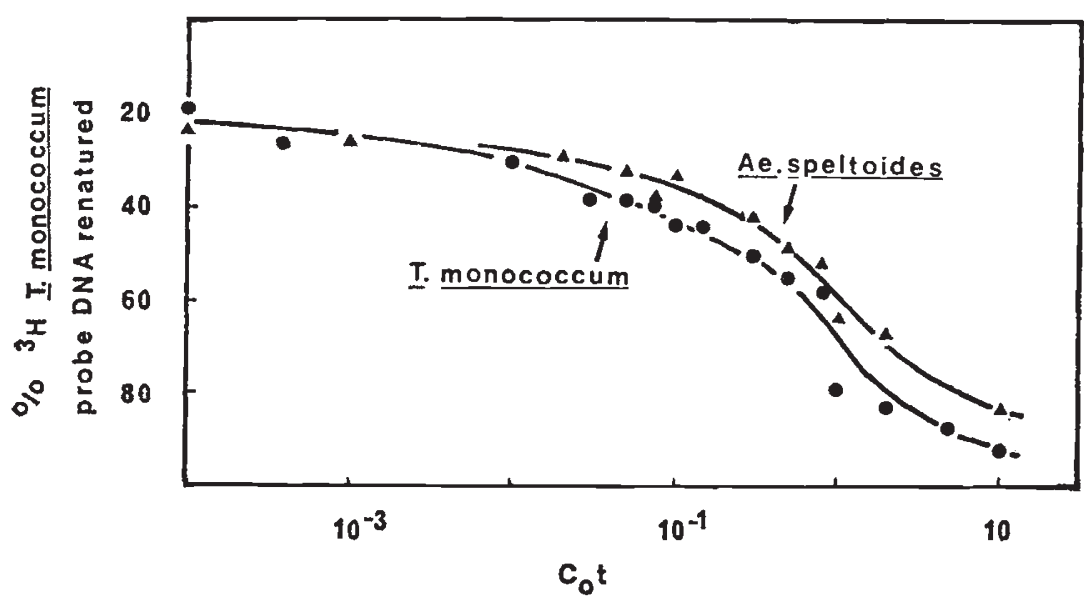

FIG. 3.-Hybridisation of $T$. monococcum highly repeated sequences to Ae. speltoides and T. monococcum repeated sequences. "Nick translated" T. monococcum DNA was incubated with a large excess of denatured, sheared unlabelled Ae. speltoides $(\mathbf{\Lambda}-\mathbf{\Lambda})$ or T. monococcum (- DNA in $0.12 \mathrm{M}$ phosphate buffer at $60^{\circ} \mathrm{C}$. The proportion of labelled DNA in the duplex fraction was determined by hydroxyapatite chromatography.

T. monococcum appears not to have sequences (detectable by the methods employed here) in such a high copy number as does Ae. speltoides where renaturation started around $\mathrm{C}_{0} \mathrm{t} 10^{-4}$ (fig. 2).

\section{Discussion}

The extent of hybridisation between DNAs from Triticum, Aegilops and Secale species indicates that the repeated sequence complements of these genomes are very similar. Most of the repeated sequence families in each of these species are related to families in each of the other species. This is expected from studies for such closely related species (Flavell et al., 1977). The degree of similarity of repeated sequences between closely related species is an important topic for study but in this paper we have focused upon the detection and analysis of repeated sequence differences between the species. From the analysis of sequence differences it is possible to infer how chromosomes change during the evolution of distinct species. 


\section{(i) Highly repeated sequence $D \mathcal{N} A$ and species divergence}

The classification of all the species studied in this paper into different genera or groups by cytogeneticists and taxonomists has not been straightforward (Mackey, 1954; Bowden, 1959). One difficulty is that within the range of Triticum species there are diploid, tetraploid and hexaploid forms, these polyploid forms having been derived by combination of a diploid from the Triticum group of species with diploids classified as Aegilops species. Thus separation of Triticum species and Aegilops species into different genera leads to difficulties when the polyploid forms of Triticum are considered.

The studies reported in this paper clearly indicate that the most highly repeated sequence DNA fraction of the diploid Aegilops representative we selected (Aegilops speltoides) is more closely related to the DNAs of Aegilops species than to the DNAs of diploid Triticum species (Triticum monococcum and Triticum boeoticum isolates T. thaoudar, T. aegilopoides and T. urartu, see table 3). The separation of diploid Triticum and Aegilops groups using DNA hybridisation techniques, correlates well with the separation of Triticum and Aegilops species into different genera. However, the distinction between Aegilops species and diploid Triticum species by DNA hybridisation is not complete; members of the vertebrata section of the Aegilops appear close to the diploid Triricum species (table 3 ). As would be expected, the polyploid Triticum species which have Aegilops species in their parentage give hybridisation results more like Aegilops species than Triticum species, using highly repeated sequences from Aegilops speltoides as probe DNA.

The Aegilops genus has been divided into six sections on the basis of morphological and cytogenetic criteria (see table 3 and Kihara and Tanaka, 1970). It is interesting to note that the diploid and tetraploid species, classified in the vertebrata section on the basis of ear morphology, appear to show lower hybridisation to the Aegilops speltoides $10^{-2}$ DNA probe than all the other Aegilops species. This result suggests highly repeated sequence DNA comparisons may also be useful for classifying species into different sections of a genus. However, considerably more comparisons carried out in a more detailed way would be necessary to distinguish reliably all the various Aegilops sections.

Although the Aegilops speltoides $\mathrm{C}_{0}$ t $10^{-2} \mathrm{DNA}$ hybridised more to Aegilops species' DNAs than to diploid Triticum species DNAs, the hybridisation to homologous Aegilops speltoides DNA was considerably greater (table 3). This suggests that Aegilops speltoides possesses a very highly repeated sequence DNA pattern which is species-specific. The T. monococcum and T. boeoticum accessions we studied differed in their hybridisation with the $\mathrm{C}_{0} \mathrm{t} 10^{-2} \mathrm{DNA}$ from $A e$. speltoides (table 3 ). This also points to species-specific patterns of highly repeated sequences.

In a previous paper we showed that quantitative changes in families of repeated sequences occur sufficiently often during evolution to enable species from the related genera Triticum, Secale, Hordeum and Avena to be distinguished easily. Furthermore, the magnitude of the DNA differences between the species was related to the extent of the evolutionary divergence that had occurred between the genera.

The species studied in this paper were more closely related to one another than those studied previously. The magnitude of the repeated 
sequence DNA differences were also considerably less, endorsing the correlation between species divergence and repeated sequence DNA divergence. Our ability to detect repeated sequence DNA differences between species within a genus supports the hypothesis that speciation is always accompanied by quantitative nucleotide sequence changes. The possibility that these chromosomal changes might drive speciation is particularly interesting. If gross chromosomal changes are major factors in causing speciation then changes such as those we have recognised here in the repeated sequence fraction of the chromosomes cannot be ignored in discussions of speciation (see Jones, 1972; Hatch et al., 1976; Jones et al., 1976).

\section{(ii) Highly repeated sequences and the diploid genomes of hexaploid wheat}

The similar hybridisation of labelled hexaploid wheat DNA to $A e$. speltoides and Ae. squarrosa DNAs as to hexaploid wheat DNA (fig. 1) implies that all the families of repeated sequences in the A, B and D genomes of wheat are found in the $\mathrm{B}$ and $\mathrm{D}$ genomes, assuming $A e$ speltoides and $A e$. squarrosa are closely related to the B and D genomes respectively of hexaploid wheat. Some repeated sequences were detected in $\mathcal{T}$. monococcum rapidly reannealing DNA which did not hybridise to Ae. speltoides DNA (fig. 3) but these accounted for about only 0.5 per cent of the $T$. monococcum genome and so would not be detectable in the experiments of fig l, even assuming they were present in the A genome of hexaploid wheat. The presence of the same families in different genomes does not necessarily imply that each family contains the same number of copies of a repeat in each genome. The lower hybridisation of $\mathrm{C}_{0} \mathrm{t} 10^{-2}$ DNA from hexaploid wheat to $A e$. squarrosa DNA than to $\mathcal{T}$. aestivum and $\mathcal{T}$. dicoccoides DNA (table 2) implies that the highly repeated sequences of hexaploid wheat are present in lower copy numbers in Ae. squarrosa.

Approximately 11 per cent of the hexaploid wheat genome appears to consist of repeated sequences not found substantially repeated in T. monococcum (table 1). How many families are in this 11 per cent and how many repeats of each kind of sequence cannot be inferred from results obtained so far. A significant fraction of the 11 per cent might be sequences repeated over $0.25 \times 10^{6}$ times in the hexaploid wheat genome since the $\mathrm{C}_{0} \mathrm{t} 10^{-2}$ fractions of hexaploid wheat showed low hybridisation to $T$. boeoticum DNA (table 2). However, most of the repeated sequences not detected in $T$. monococcum are probably of lower copy number, renaturing between $\mathrm{C}_{0} \mathrm{t} 10^{-2}$ and $\mathrm{C}_{0} \mathrm{t} 10$. This conclusion is supported by the results in fig. 1 where lower hybridisation of wheat DNA to $T$. monococcum DNA was detected only at higher $\mathrm{C}_{0} \mathrm{t}$ values.

It has already been argued in the results section that the ability of DNAs, from different Triticum and Aegilops species of differing ploidy, to compete for the highly repeated sequences in the $\mathrm{C}_{0} \mathrm{t} 10^{-2}$ DNA fraction of hexaploid wheat (table 2) implies that a significant proportion of the very highly repeated sequences in this $\mathrm{C}_{0} \mathrm{t} 10^{-2}$ fraction come predominantly from the $\mathrm{B}$ genome chromosomes. Some of these sequences are repeated in the $\mathrm{A}$ and $\mathrm{D}$ genomes, possibly in a lower frequency, while a small proportion are not found in the repeated sequence fractions of the $\mathrm{A}$ genome. The similarity of the $\mathrm{C}_{0} \mathrm{t} 10^{-2}$ DNA fractions from hexaploid wheat and from Aegilops speltoides with respect to their hybridisation patterns to Triticum and Aegilops 
DNAs (tables 2 and 3 ) is consistent with the B genome of hexaploid wheat coming from Aegilops speltoides or a closely related diploid. Triticum urartu, suggested as a possible B genome donor on the basis of grain proteins (Johnson, 1975), does not possess a highly repeated sequence complement similar to that of the B genome of wheat (table 3 ).

The concentration in the $\mathrm{B}$ genome of the most highly repeated sequences of hexaploid wheat suggests this fraction may be an easily isolated source of sequences to distinguish $\mathrm{B}$ genome chromosomes from $\mathrm{A}$ and $\mathrm{D}$ genome chromosomes following its in situ hybridisation to wheat metaphase chromosomes. This was indeed shown to be the case by Gerlach (personal communication). The $\mathrm{C}_{0}+10^{-2}$ fraction from Aegilops speltoides would also be expected to be a similarly useful in situ hybridisation marker DNA for B genome chromosomes.

Several laboratories have shown that a satellite can be isolated from hexaploid wheat DNA after centrifugation in $\mathrm{Ag}^{+} \mathrm{Cs}_{2} \mathrm{SO}_{4}$ gradients (Huguet and Jouanin, 1972; Ranjekar et al., 1976; Peacock et al., 1977). This simple sequence satellite hybridises strongly to all the B genome chromosomes and to two A genome chromosomes of hexaploid wheat but hardly at all to the remaining $\mathrm{A}$ and $\mathrm{D}$ genome chromosomes when tested by in situ hybridisation (Peacock et al., 1977). These satellite sequences are present in the $\mathrm{C}_{0} \mathrm{t} 10^{-2}$ fraction from hexaploid wheat but since they occupy only 0.1 per cent of the wheat genome they must constitute only a small proportion of all the $\mathrm{C}_{0} \mathrm{t}$ $10^{-2}$ DNA. Nevertheless they are responsible for some of the preferential hybridisation of the $\mathrm{C}_{0} \mathrm{t} 10^{-2}$ DNA to the $\mathrm{B}$ genome-like species. This satellite is also present in Aegilops speltoides DNA but is not readily detectable in $\mathrm{Ag}^{+} \mathrm{Cs}_{2} \mathrm{SO}_{4}$ gradients of Triticum monococcum DNA (unpublished results). This finding substantiates the claim that the species closely related to the $\mathrm{A}$ and $\mathrm{B}$ genome donors of hexaploid wheat differ in the amounts of $\mathrm{Ag}^{+}$ binding "satellite" repeated sequences they possess.

\section{REFERENCES}

BARNES, S. R., WEBB, D. A., AND DOVER, G. 1978. The distribution of satellite and main band DNA components in the melanogaster species subgroups of Drosophila. Chromosoma (Berl.) , 67, 341-363.

BELL, G. D. H. 1965. The comparative phylogeny of the temperate cereals. In Essays in Crop Plant Evolution, ed. J. Hutcheson, pp. 70-102. Cambridge University Press, Cambridge, England.

BENDICH, A. J., AND MCCARTHY, B. J. 1970. DNA comparisons among barley, oats, rye and wheat. Genetics, 65, 545-566.

BOWDEN, w. M. 1959. The taxonomy and nomenclature of the wheats, barleys and ryes and their wild relatives. Canad. $\mathcal{F}$. Bot., 37, 657-684.

BROWN, D. D., AND WEBER, c. s. 1968. Gene linkage by RNA-DNA hybridisation. Unique DNA sequences homologous to 4 s RNA, 5s RNA and ribosomal RNA. F. Mol. Biol., 34, 661-680.

CHOor, w. Y. 1971. Comparison of the DNA ofsix Vicia species by the method of DNADNA hybridisation. Genetics, 68, 213-230.

FLAVELl, R. B., O'DELl, M., RIMPAU, J., AND SMITH, D. B. 1978. Biochemical detection of alien DNA incorporated into wheat by chromosome engineering. Heredity, 40, 439-455.

FLAVELL, R. B., RIMPAU, J., AND SMITH, D. B. 1977. Repeated sequence DNA relationships in four cereal genomes. Chromosoma (Berl.), 63, 205-222.

FLAVELL, R. B., AND SMITH, D. B. 1976. Nucleotide sequence organisation in the wheat genome. Heredity, 37, 231-252.

GOldBERG, R. B., BEMIS, W, P., AND SIEGEL, A. 1972. Nucleic acid hybridisation studies within the genus Cucurbita. Genetics, 72, 253-266. 
HATCH, F. T., BODNER, A. J., MAZRIMAS, J. A., AND MOORE, D. A. 1976. Satellite DNA and cytogenetic evolution. DNA quantity, satellite DNA and karyotypic variations in Kangaroo rats (genus Dipodomys). Chromosoma (Berl.), 58, 155-168.

HUGUet, T., AND JOUANIN, L. 1972. Wheat DNA: study of the heavy satellite in $\mathrm{Ag}^{+}$$\mathrm{Cs}_{2} \mathrm{SO}_{4}$ density gradient. Biochem Biophys Res. Comm., 46, 1169-1174.

JoHnson, B. L. 1975. Identification of the apparent B-genome donor of wheat. Canadian $\mathcal{Z}$. of Genetics and Cytology, 17, 21-39.

JoNes, K. w. 1972. Repetitive DNA sequences in animals, particularly primates. In Chromosomes Today, ed. P. L. Pearson and K. R. Lewis, 5, 305-313. Wiley, New York. JoNes, K. w., Prosser, J., CORNEo, G., GINELlI, E., AND Bobrow, M. 1976. Satellite DNA, constitutive heterochromatin and human evolution. In Modern Aspects of Cytogenetics: Constitutive Heterochromatin in Man, ed. R. A. Pfeiffer, pp. 45-74.

KIHARA, H., AND TANAKA, M. 1970. Addendum to the classification of the genus Aegilops by means of genome analysis. Wheat Information Service, 30, 1-2. Kyoto University, Kyoto, Japan.

Mackey, J. 1954. The taxonomy of hexaploid wheat. Svenok bot. Tidskr., 48, 579.

MIZUNO, s., ANDREWS, C., AND MACGREGOR, H. C. 1976. Interspecific " common" repetitive DNA sequences in salamanders of the genus Plethodon. Chromosoma (Berl.), 58, 1-31.

PEACOCK, w. J., LOHE, A. R., GERLACH, w. L., DUNSMUIR, P., DENNIS, E. S., AND APPELS, R. 1977. Fine structure and evolution of DNA in heterochromatin. Cold Spring Harbor Symp. Quant. Biol., XLII, 1121-1135.

Ranjekar, P. K., PAllotta, D., AND lafontaine, J. G. 1976. Analysis of the genome of plants. II. Characterisation of repetitive DNA in barley (Hordeum vulgare) and wheat (Triticum aestivum). Biochim Biophys Acta, 425, 30-40.

RICE, N. R. 1972. Change in repeated DNA in evolution. Brookhaven Symp'm, 23, 44-79.

RIGE, N., AND ESPOSITO, P. 1973. Relatedness among several hamsters. Carnegie Institution. Year Book, 72, 200-204.

RIMPAU, J., SMITH, D. B., AND FLAVELL, R. B. 1978. Sequence organisation analysis of the wheat and rye genomes by interspecies DNA DNA hybridisation. 7. Molec. Biol., 123, 327-359.

SMITH, D. B., AND FLAVELL, R. B. 1974. The relatedness and evolution of repeated nucleotide. sequences in the DNA of some Gramineae species. Biochem. Genetics, 12, 243-256.

SMITH, D. B., AND FLAVELL, R. B. 1975. Characterisation of the wheat genome by renaturation kinetics. Chromosoma (Berl.), 50, 223-242.

STEIN, D. B., AND THOMPSON, w. F. 1975. DNA hybridisation and evolutionary relationships. in three Osmunda species. Science, 189, 888-890.

straus, N. A. 1972. Reassociation of bean DNA. Carnegie Institution Year Book, 71, 257-259.

studier, F. w. 1965. Sedimentation studies of the size and shape of DNA. J. Molec. Biol., $11,373-390$.

sutron, w. D. 1971. A crude nuclease preparation suitable for use in DNA reassociation. experiments. Biochim Biophys Acta, 240, 522-531. 